\title{
Eukasz Dryblak
}

Warszawa

\section{Inspiracja i formy współpracy polskich instytucji państwowych z wydawcami i redakcjami pism rosyjskich w latach 1919-1935 — zarys problematyki}

Wraz z wybuchem rewolucji w 1917 r. w Rosji nastał czas wojny domowej, która wywołała exodus Rosjan do krajów ościennych. Wielu uchodźców skierowało się na ziemie zachodnie Imperium, w tym do byłego Królestwa Polskiego, a od listopada 1918 r. odnowionego państwa polskiego, zamieszkiwanego również przez mniejszość rosyjską. W samej tylko Warszawie w 1919 r. liczba uchodźców sięgała 36 tys. ${ }^{1}$ W latach 1918-1921 przez Polskę przewinęło się kilkaset tysięcy rosyjskich uchodźców szukających schronienia przed bolszewikami. Niektórzy z nich zostawali w Polsce, większość jednak traktowała ją jako kraj tranzytowy w drodze do Niemiec, Francji, Czech, Wielkiej Brytanii czy Stanów Zjednoczonych Ameryki. Niewielka część z nich powróciła po wojnie polsko-bolszewickiej do Rosji bądź przyjęła, jeśli miała do tego prawo, obywatelstwo polskie; pozostali wybrali status emigranta $^{2}$. Ostatnie przed wybuchem wojny większe przemieszczenia Rosjan między Polską a Europą Zachodnią nastąpiły w pierwszej połowie lat dwudziestych. Jedną z przyczyn była utrata nadziei na szybki wybuch konfliktu między Polską a ZSRS, który pozwoliłby podnieść sprawę powrotu ponadmilionowej rzeszy emigrantów rosyjskich do ojczyzny. Ostatecznie liczebność społeczności rosyjskiej w Polsce ukształtowała się na poziomie poniżej 200 tys., z czego połowę stanowili emigranci i uchodźcy, a połowę obywatele Rzeczypospolitej, w tym moskalofile oraz staroobrzędowcy.

Emigranci rosyjscy zamieszkiwali głównie duże miasta oraz mniejsze miejscowości położone w województwach wschodnich, gdzie przebywała większość mniejszości rosyjskiej. Ich najważniejszymi ośrodkami były Warszawa ${ }^{3}$, Wilno — będące jednocześnie naj-

\footnotetext{
${ }^{1}$ A. Juzwenko, Polska a ,biała” Rosja (od listopada 1918 do kwietnia 1920 r.), Wrocław 1973, s. 117.

2 Dla rozróżnienia terminów „emigrant” i ,uchodźca” posłużymy się definicją Dimitriâ Filosofova i Vladimira Branda, zawężającą znaczenie słowa emigrant jedynie do grupy osób, które opuściły Rosję w celu kontynuacji walki z reżimem bolszewickim; pozostali są — w myśl tej definicji — jedynie uchodźcami, zob.: D. Filosofov, Ot čego zavisit vozroždenie êmigracii?, „Meč”, nr 1-2, 20 V 1934, s. 6; V. Brand, ,Frontovniki” ' ,,tyloviki”, ibidem, nr 21, 7 X 1934, s. 2.

33979 osób deklarowało język rosyjski jako ojczysty, 3326 z nich było wyznania prawosławnego, zob.: Drugi powszechny spis ludności z dn. 9 XII 1931 r. Miasto st. Warszawa, Warszawa 1937, s. 48.
} 
większym skupiskiem mniejszości rosyjskiej ${ }^{4}$, a także — w mniejszym stopniu — Lwów oraz Łódź ${ }^{6}$. Poza tym najliczniej byli reprezentowani w województwach: białostockim ${ }^{7}$ Białystok, Grodno, Hajnówka (we wschodniej części województwa mieszkało ok. 2 tys. bałachowców); wileńskim ${ }^{8}$ — Wilno, Nowa Wilejka; nowogródzkim ${ }^{9}$ — Nowogródek, Lida, Baranowicze, Słonim, Stołpce; poleskim ${ }^{10}$ - Brześć nad Bugiem, Pińsk, Dawidgródek, Sarny; wołyńskim ${ }^{11}$ — Łuck, Równe, Zdołbunów, Włodzimierz, Kowel, Dubno, Ostróg, Krzemieniec, Kołki (większzość ziemian rosyjskich zamieszkiwała województwa poleskie, wołyńskie i wileńskie) $)^{12}$, po kilkuset we lwowskim — Lwów; tarnopolskim — Tarnopol; i stanisławowskim. Część mniejszości rosyjskiej zamieszkiwała również obszary wiejskie w powiatach: wileńsko-trockim, święciańskim, brasławskim, dziśnieńskim, wilejskim, duniłowickim województwa wileńskiego (głównie staroobrzędowcy) ${ }^{13}$, w pasie granicznym, w województwach wołyńskim, poleskim oraz nowogródzkim, oraz w niektórych powiatach województwa lwowskiego (głównie moskalofile). Przynajmniej kilkudziesięcioosobowe kolonie znajdowały się we wszystkich dużych i wielu średnich miastach Polski.

Obecność Rosjan w II Rzeczypospolitej, a w szczególności na jej Kresach Wschodnich, z jednej strony niosła ze sobą pewne zagrożenia dla jej bezpieczeństwa. Z drugiej strony obecni w Polsce Rosjanie mogli być wykorzystani zarówno jako karta $\mathrm{w}$ negocjacjach politycznych na arenie międzynarodowej, jak i element kreowania wi-

${ }^{4} 7372$ osób deklarowało rosyjski jako język ojczysty, 5276 z nich było wyznania prawosławnego, natomiast ok. 1800 staroobrzędowego, zob.: Drugi powszechny spis ludności z dn. 9 XII 1931 r. Miasto Wilno, Warszawa 1937, s. 11. „Gdy przyjechałem do Wilna [...] Inteligencja rosyjska — właściciele licznych nieruchomości, dawni urzędnicy carscy - stanowiła zwartą i ruchliwą grupę. Utrzymywała kontakt z dość licznie reprezentowanymi właścicielami majątków ziemskich”, J. Kirchmayer, Pamiętnik, Warszawa 1987, s. 55.

${ }^{5} 462$ osób deklarowało rosyjski jako język ojczysty, w tym 348 prawosławnych, zob.: Drugi powszechny spis ludności z dn. 9 XII 1931 r. Miasto Lwów, Warszawa 1937, s. 11.

${ }^{6} 871$ osób deklarowało rosyjski jako język ojczysty, w tym 693 prawosławnych; zob.: Drugi powszechny spis ludności z dn. 9 XII 1931 r. Miasto Łódź, Warszawa 1937, s. 14.

710 506, w tym 9791 prawosławnych, zob.: Drugi powszechny spis ludności z dn. 9 XII 1931 r. Województwo biatostockie, Warszawa 1938, s. 24.

${ }^{8}$ Zob. przyp. 71 i 75.

9 6794, w tym 6489 prawosławnych, zob.: Drugi powszechny spis ludności z dn. 9 XII $1931 \mathrm{r}$. Województwo nowogródzkie, Warszawa 1938, s. 19.

${ }_{10} 16$ 198, w tym 15887 prawosławnych, zob.: Drugi powszechny spis ludności z dn. 9 XII $1931 \mathrm{r}$. Województwo poleskie, Warszawa 1938, s. 20. Referat przesłany przez wojewodę Wacława Kostka-Biernackiego do MSW zawiera informację o 25050 Rosjanach (2,2 proc. ludności województwa) zamieszkujących w 1931 r. województwo poleskie, AAN, MSW, Urząd Wojewódzki w Brześciu, sygn. 41, k. 3-4. ${ }_{11} 23$ 387, w tym 22771 prawosławnych, zob.: Drugi powszechny spis ludności z dn. 9 XII 1931 r. Województwo wołyńskie, Warszawa 1938, s. 22. W sprawozdaniu wojewody wołyńskiego z 1934 r., odwołującym się do danych z 1931 r., liczba Rosjan została określona na 4923 (sic!). Henryk Józewski uważał większość Rosjan za zrusyfikowanych Ukraińców, a tylko niewielką część z nich za przybyszów z głębi Rosji, co również mogło zaciążyć na podanych danych, AAN, MSW, sygn. 85, k. 44.

${ }^{12} \mathrm{~W}$ powiecie zdołbunowskim Rosjanie stanowili 1,6 proc. ludności, ale posiadali aż 7,67 proc. całej ziemi (31 gospodarstw poniżej 50 ha, 10 gospodarstw 50-500 ha, 5 majątków powyżej 500 ha), Materiały dotyczące spraw narodowościowych w powiatach rówieńskim i zdołbunowskim w 1931 r., AAN, MSW, sygn. 944, k. 114.

${ }^{13}$ W 1931 r. w województwie wileńskim, bez Wilna, mieszkało 35981 osób deklarujących język rosyjski jako ojczysty (w tym ok. 9624 prawosławnych i ok. 25 tys. staroobrzędowców), z czego ponad 33 tys. mieszkało na wsi, zob.: Drugi powszechny spis ludności z dn. 9 XII 1931 r. Województwo wileńskie, Warszawa 1936, s. 10. 
zerunku Polski oraz, paradoksalnie, jako czynnik państwotwórczy na Kresach poprzez m.in. inspirację prasy ${ }^{14}$. Pierwszy przypadek został dokładnie opracowany przez Andrzeja Nowaka w jego monografii dotyczącej polityki Józefa Piłsudskiego wobec „trzech Rosji” (bolszewickiej, „białej” oraz Savinkova) ${ }^{15}$. Drugi został zasygnalizowany w niepublikowanej pracy doktorskiej Wojciecha Stanisławskiego ${ }^{16}$, pracach Joanny GierowskiejKałłaur $^{17}$ oraz Adama R. Suławki ${ }^{18}$. Temu przypadkowi poświęcono również poniższy artykuł.

\section{Wojna a kontakty polsko-rosyjskie 1919-1920}

Polskie władze państwowe, zarówno na szczeblu najwyższym, jak również w terenie, już w pierwszej połowie 1919 r. dostrzegły możliwość, a może raczej potrzebę zagospodarowania ,żywiołu” rosyjskiego, kulturowo dominującego w wielu powiatach byłych guberni wileńskiej, grodzieńskiej, mińskiej oraz wołyńskiej, mającego szczególny wpływ na Żydów, Białorusinów, Ukraińców, staroobrzędowców, moskalofilów, a także liczną rzeszę nieokreślonych narodowościowo mieszkańców Polesia, tzw. tutejszych. Oficerowie Oddziału II Sztabu Generalnego w umiejętnym wspieraniu i inspiracji prasy rosyjskiej wydawanej zarówno w Polsce, jak i poza jej granicami widzieli możliwość zwalczania wrogiej Polsce propagandy oraz efektywnej poprawy wizerunku młodego państwa polskiego, i to za pomocą pism prowadzonych przez Rosjan, w swej masie wrogo do niego ustosunkowanych.

W 1919 r. najważniejszymi ośrodkami rosyjskimi znajdującymi się na terenie objętym polską władzą były Warszawa, Wilno oraz Mińsk. We wszystkich tych trzech miastach, a ponadto w Grodnie i Białymstoku już od początku roku zaczęły pracę rosyjskie redakcje, wydające czasopisma, zazwyczaj na niskim poziomie, jednak jedyne, jakie docierały do rosyjskojęzycznych mieszkańców Kresów Wschodnich. Najprężniej rozwijała się prasa w stolicy, gdzie przebywała największa liczba Rosjan. Uchodźcy liczyli, że karta się odwróci i niedługo będą mogli wrócić do swoich domów. Należy pamiętać, że zwycięstwo bolszewików nie było oczywiste. Wręcz przeciwnie, ,biali”, korpusy interwencyjne, Polacy, Ukraińcy to tylko część wrogów, z którymi musiała uporać się nowa władza, panująca jedynie nad terenami Rosji centralnej, od Petersburga do Moskwy. W uchodźcach narastała chęć politycznego zaangażowania, która wyrażała się m.in. w wielości powstających tytułów prasowych oraz próbach założenia komitetu politycznego w Warszawie, co jednak na początku 1919 r. zostało zdecydowanie odrzucone przez polskie $\mathrm{MSZ}^{19}$. Z drugiej strony można się zastanawiać, czy jedynym powodem wydawniczej aktywności Rosjan była rzeczywiście chęć posiadania swoich organów politycznych w celu manifestowania poglądów, spierania się o przyszły kształt

\footnotetext{
${ }^{14}$ W skali europejskiej Rosjanie posiadali kilka tysięcy czasopism, w tym w Polsce ponad sto tytułów, z czego duża część była efemerydami.

${ }^{15}$ A. Nowak, Polska i trzy Rosje. Studium polityki wschodniej Józefa Piłsudskiego (do kwietnia 1920 roku), Kraków 2001.

${ }^{16}$ W. Stanisławski, Myśl polityczna emigracji rosyjskiej w II Rzeczpospolitej: interpretacje przeszłości i koncepcje polityczne, mps. pracy doktorskiej w Bibliotece Instytutu Historycznego UW.

${ }^{17}$ J. Gierowska-Kałłaur, Straż Kresowa a Zarząd Cywilny Ziem Wschodnich. Współdziałanie czy rywalizacja?, Warszawa 1999; Raporty Straży Kresowej 1919-1920 Ziem Pótnocno-Wschodnich opisanie, oprac. J. Gierowska-Kałłaur, Warszawa 2011.

${ }^{18}$ A. R. Suławka, Idea wspótpracy polsko-rosyjskiej w myśli politycznej rosyjskiej emigracji w Polsce (lata 1918-1939), „Przegląd Filozoficzny” 2013, t. LXXXVII, z. 3, s. 221-238.

${ }_{19}$ W marcu 1919 r. MSW zatwierdziło statut, wyłączający z kompetencji Komitetu Rosyjskiego sferę polityczną, A. Juzwenko, op. cit., s. 109.
} 
Rosji czy też komunikowania z państwem polskim. Otóż rzeczywistość okazała się bardziej skomplikowana.

W większości czasopism rosyjskich funkcję redaktora naczelnego lub odpowiedzialnego pełnili Rosjanie żydowskiego pochodzenia, którzy pozostali w 1915 r. w Warszawie lub powrócili z Rosji. Niektórzy z nich byli wydawcami jeszcze przed wybuchem wojny, tak jak Michał Usman. Wydając rosyjską prasę, korzystali z żydowskiej infrastruktury i zaplecza przejawiającego się w drukarniach, wydawnictwach, a także dziennikarzach ${ }^{20}$. Nie można oczywiście zapominać o rzeszy bolszewickich szpiegów w szeregach uchodźców, którzy również byli zainteresowani kontrolą i odpowiednim przekazem prasy rosyjskiej wydawanej w Polsce. Do tego dochodziły interesy państwa polskiego, które ingerowało w wydawaną prasę poprzez cenzurę, a także starało się skierować jej przekaz w stronę propaństwową.

Największe zainteresowanie władz polskich wzbudzili wydawcy rosyjscy żydowskiego pochodzenia. Tylko oni liczyli się na rynku prasy rosyjskiej. Nie bez znaczenia były również ich poglądy polityczne, które najogólniej można by określić liberalno-demokratycznymi. Jedynym czasopismem, które było kierowane przez Rosjanina, a zarazem nie podlegało wpływom ani bolszewickim, ani polskim, było „Eho”, przemianowane następnie na „Russkoe Eho”. Było ono jednak efemerydą wydawaną tylko od lipca do września 1919 r. Jego redaktorem był Grigorij Nowicki, sympatyzujący z gen. Antonem Denikinem ${ }^{21}$, z punktu widzenia władz polskich mniej przydatny ze względu na swoje nacjonalistyczne oraz antysemickie poglądy ${ }^{22}$.

W wyniku obserwacji czasopism rosyjskich w drugiej połowie 1919 r. pracownicy Towarzystwa Straży Kresowej oraz Oddziału II SG postanowili przejąć nad nimi kontrolę. Najwcześniej datowanym dowodem na zainteresowanie prasą rosyjską, do którego udało się dotrzeć autorowi, są listy współpracownika TSK z maja i czerwca 1919 r. Zwracał on w nich uwagę kierownikowi Wydziału Prasowo-Wydawniczego Melchiorowi Wańkowiczowi, że duża część ludności żydowskiej i rosyjskiej chętniej czytała dziennik „Varšavskaâ Reč” niż „Svobodnoe Slovo”, które ponadto reprezentowało szkodliwe dla państwa polskiego stanowisko. Podkreślił również, że warto byłoby zapełnić jej miejsce lojalnym wobec władz polskich pismem rosyjskim, dodając, że ,[...] dużo ludności na Kresach umie czytać tylko po rosyjsku"23. Dwa miesiące później Wańkowicz opracował Memoriat w sprawie potrzeby wydania pisma w języku rosyjskim dla ludności Kresów Wschodnich. Argumentował, że

\footnotetext{
${ }^{20}$ Pisma wydawane i redagowane przez Rosjan żydowskiego pochodzenia, które do ukazania się dziennika „Svoboda” w lipcu 1920 r. dominowały na rynku prasy rosyjskiej, to dzienniki: „Varšavskaâ Reč” 1919, red. G. Ĺedkevič, „Svobodnoe Slovo” 1919, red. V. Horvitz-Samojlov, „Varšavskoe Slovo” 1920, red. V. Horvitz-Samojlov, „Novoe Varšavskoe Slovo” 1920, red. V. Horvitz-Samojlov; tygodniki: „Buduŝee” 1919, red. G. Ĺedkevič, „Nedelâ Svobodnago Slova” 1919, red. V. Horvitz-Samojlov.

${ }^{21}$ G. Nowicki (1885-1955), inżynier, na przełomie 1918/1919 r. powrócił do Warszawy, gdzie założył biuro pośrednictwa zatrudniające trzynastu ludzi i zajmujące się m.in. wysyłką listów do Rosji, możliwe że utrzymywał tajny kontakt z gen. A. Denikinem oraz baronem P. Wranglem. W 1919 r. był redaktorem czasopism „Eho” i „Russkoe Eho” - w wyniku konfliktu z Komitetem Rosyjskim oraz wydawcami rosyjskimi Georgiem Ĺedkevičem oraz Vladimirem Horvitz-Samojlovem, a także z braku środków szybko zamknął swoje czasopismo. Był redaktorem dwóch numerów almanachu „Rus””; w latach 1921-1923 wydawał w Berlinie czasopismo „Čto Delat'?”, następnie w latach 1937-1939 organ Nacionalnogo Obedineniâ, „Rus”, , AAN, MSW, sygn. 1195, k. 154; biogram — http://www.dom museum.ru/index.php?m=dist\&pid=8255\&PHPSESSID=da6e293f80df7744931d451004f6ae4b (dostęp: 30 XII 2014).

22 „Russkoe Eho”, nr 10 z 22 VIII 1919, s. 2-3; nr 13 z 26 VIII 1919, s. 1; nr 26 z 22 IX 1919, s. 1.

${ }^{23}$ AAN, Towarzystwo Straży Kresowej (dalej: TSK), sygn. 408, k. 1-5.
} 
rosyjski jest najpowszechniej rozumianym oraz poważanym językiem na Kresach. Ponadto, co nie było również bez znaczenia, wydawanie pisma rosyjskiego było tańsze i łatwiejsze niż kilku pism w językach narodowych. Słusznie stwierdzał, że w tym czasie to Rosjanie mieli lepsze warunki do asymilacji narodowej Kresów, za czym przemawiały „,...] rutyna przeszłości, łączność kulturowa, dwustronność agitacji i język rosyjski. Dwustronność agitacji, to - jednako nam wrogie i jednako centralizujące na rzecz Wielkiej Rosji wpływy bolszewizmu i Kołczaka. [...] musimy podjąć wydawnictwo rosyjskiego pisma, które będzie stanowić należną przeciwwagę, zarówno rozgałęzionej propagandzie bolszewickiej, idącej z zewnątrz, bądź nielegalnie, jak i szeroko kolportowanemu z Warszawy «Russkiemu Słowu» [w tym czasie w Warszawie nie wychodziło pismo o takim tytule, być może chodziło tutaj o „Svobodnoe Slovo” lub „Russkoe Eho” — Ł. D.], z Grodna «Grodzieńskiemu Słowu», oraz z Białegostoku tamtejszemu rosyjskiemu pismu [„Golos Belostoka” — Ł. D.]"24. Nowe pismo miało mieć charakter obiektywno-informacyjny, przybliżający sprawy polskie oraz kwestię reformy agrarnej ${ }^{25}$. Poprzez zaangażowanie największych wydawców pism rosyjskich Georgiâ Ledkeviča i Vladimira Horvitz-Samojlova osiągnięto jednocześnie dwie korzyści: wyeliminowano najgroźniejszych konkurentów na rynku rosyjskojęzycznym oraz utworzono, korzystając z ich zaplecza, lojalną wobec państwa polskiego prasę. Słusznie zauważono w TSK, że „byłoby to zadaniem niezmiernie trudnem, gdyby chcieć powołać dopiero takie pismo do życia. Otrzymałoby ono od razu markę półurzędowca polskiego i miało utrudniony debiut. Natomiast wskazanem jest nabycie jedynego pisma, które obejmuje całe kresy «Warszawskaja Riecz»" "26. Obaj redaktorzy 11 IX 1919 r. sprzedali swoje prawa do tytułów „Varšavskaâ Reč” i „Svobodnoe Slovo” spółce z o.o. „Russkoe Izdatelstvo” kierowanej przez zarządcę Wacława Ciechowskiego oraz podpisali deklarację, iż nie będą do czasu egzystencji spółki wydawać osobiście ani przez osobę trzecią codziennego pisma rosyjskiego ${ }^{27}$. Po wykonaniu tejże operacji właściciele spółki (prawdopodobnie większość udziałów znajdowała się w rękach ludzi pracujących lub podstawionych przez TSK) złożyli z urzędu zarządcę Ciechowskiego i powołali na jego miejsce Stefana Szwedowskiego, zastępcę kierownika Wydziału Prasowo-Wydawniczego TSK. Jednocześnie ze złożeniem Ciechowskiego ze stanowiska redaktora „Varšavskoj Reči” ustąpiła jego żona Lovšyn-Ciechowska. Tym samym gazeta była wydawana do końca 1919 r. przez „Russkoe Izdatielstvo” pod redakcją Wladimira Potapowa, dotychczasowego sekretarza gazety ${ }^{28}$. Z tego okresu w aktach TSK zachowała się bardzo ciekawa instrukcja, według której ton pisma miał być liberalno-demokratyczny, jednocześnie miało ono zwalczać ,[...] prądy prawicowe, atakujące rząd polski, przez co wytwarzać się będzie w czytelniku poczucie lewicowości tego rządu". Zakładała ona dyskredytację zarówno „białych”, jak i „,czerwonych”: „Czytelnik pisma ma mieć więc stale napędzanego stracha przed bolszewizmem i stale podkopywaną wiarę w szybkie odrodzenie Rosji". W kwestii prawosławia pismo miało domagać się pensji dla osób duchownych, gdyż po ich przyznaniu mogłoby sobie to przypisać jako zasługę, natomiast w stosunku do Żydów miało publikować, ale ostrożnie, by nie zrazić Rosjan, przekłady pisarzy żydowskich ${ }^{29}$. W nowym roku nie kontynuowano wydawania tego tytułu, lecz założono, dzięki umowie z Horvitz-

\footnotetext{
${ }^{24}$ „Memoriał w sprawie potrzeby wydawania pisma w języku rosyjskim dla ludności Kresów Wschodnich", AAN, TSK, sygn. 409, k. 1-4.

${ }^{25}$ Ibidem, k. 4.

${ }^{26}$ „Memoriał Wydziału Prasowo-Wydawniczego Straży Kresowej”, AAN, TSK, sygn. 409, k. 15-16.

${ }^{27}$ AAN, TSK, sygn. 408, k. 9-16.

${ }^{28}$ Ibidem, k. 31.

${ }^{29}$ Wszystkie cytaty dotyczące instrukcji, AAN, TSK, sygn. 409, k. 11.
} 
Samojlovem, „Varšavskoe Slovo”,30, wydawane przez „Svobodnoe Slovo” spółkę z o.o., od 4 stycznia do prawdopodobnie sierpnia $1920 \mathrm{r}^{31}$ Pozyskanie owego redaktora było ważnie nie tylko ze względu na ludność rosyjską ${ }^{32}$, ale również żydowską, która darzyła go zaufaniem ${ }^{33}$. Na mocy umowy redaktor zobowiązał się m.in. do postępowania zgodnie $\mathrm{z}$ instrukcjami dyrektora, który ponadto miał decydujący głos w sprawie zatrudnianych pracowników ${ }^{34}$.

W celu wzmocnienia przekazu wśród ludności rosyjskiej od lutego 1920 r. TSK zaczęło wydawać tygodnik ilustrowany „Ogoniok”35, a swoje usługi zaoferował Aleksander Gzowski ps. Junosza, były redaktor organu Komunistycznej Partii Litwy i Białorusi „Zvezda”. Wraz z wejściem Polaków do Mińska natychmiast zmienił strony i rozpoczął wydawanie propolskiego dziennika „Mińskij Kurier”. Dalszą pracę kontynuował zapewne za przyzwoleniem Oddziału II. W liście z września 1919 r. do TSK pisał: „,...] prowadzę bezwzględną akcję antybolszewicką, stojąc całkowicie po stronie Polskiej Państwowości i Władzy" "36. Proponował utworzenie nowej gazety rosyjskiej, która zastąpiłaby antypolski „Vileńskij Kurier”. Proponował powierzenie mu zarządu nad całą prasą rosyjską na Kresach i obszarach zajmowanych przez WP, dodając że owe przedsięwzięcie sfinansowałby dzięki spółce akcyjnej. W ostateczności jeśli TSK nie byłaby zainteresowana jego ofertą, prosił jedynie o wsparcie finansowe dla swojego dziennika ${ }^{37}$. Nieprzychylny Polsce „Vileńskij Kurier” został zneutralizowany wysokimi grzywnami, natomiast marzenia Gzowskiego w najlepszym wypadku mogły się zakończyć jedynie subsydiami oraz udziałem w późniejszych inicjatywach prasowych TSK. W pierwszej połowie stycznia $1919 \mathrm{r}$. trafiła do niego dwójka sławnych petersburskich pisarzy Dimitrij Merežkovski i Zinaida Gippius z sekretarzem Vladimirem Žlobinem oraz ich przyjaciel, znany krytyk literacki Dimitrij Filosofov. Wszyscy uciekli z Petersburga, przedostając się na stronę polską koło Bobrujska, skąd trafili do Mińska. Tam odbyli rozmowę z gen. Lucjanem Żeligowskim, który — jak pisze Gippius - utwierdził ich w przekonaniu, że Piłsudski chce utworzyć w Polsce rząd rosyjski, który zająłby miejsce bolszewików i umożliwił uczciwe ułożenie

${ }^{30}$ Ibidem, k. 28-30. Zob. A. Nowak, op. cit., s. 489; N. Zielińska, Towarzystwo Straży Kresowej 1918 1927, Lublin 2006, s. 166; A. R. Suławka, op. cit., s. 223.

${ }^{31}$ Między majem a sierpniem 1920 r. współpraca z Horvitzem prawdopodobnie została przerwana - zatrudniono nowego administratora Edwarda Kuleszę, AAN, TSK, sygn. 468, k. 6. Władze polskie zaczęły promować organ Rosyjskiego Komitetu Politycznego Borisa Savinkowa „Svoboda”, w którego pracach próbował wziąć udział również Horvitz, lecz bezskutecznie, Z. Gippius, op. cit., s. 459.

${ }^{32}$ Jak wspominała Z. Gippius, pismo to nie miała dobrej opinii wśród Rosjan. „Już w Mińsku wiedzieliśmy, że nazywają ją «szmatławcem». Kierowała nią ciemna postać, jakiś Żyd Horwic, gazeta bolszewizowała na całego. Nie mogliśmy pojąć, dlaczego jej nie zamykają, okazało się jednak, że Horwic był na usługach jakiejś partii prawicowej, chyba «Straży Kresowej», i był przez nią subsydiowany", Z. Gippius, op. cit., s. 459.

${ }^{33}$ „Pozyskanie tego pisma jest niezmiernie dla państwowości polskiej ważne. Trzeba spłacić dług Samojłowa, uczynić go zależnym od siebie i wsadzić swego odpowiedzialnego redaktora”, AAN, TSK, sygn. 409 , k. 22.

${ }^{34}$ AAN, TSK, sygn. 408, k. 28-30. Instrukcja dla Horvitza prawdopodobnie była sformułowana w podobnym tonie do wskazówek dla red. „Varšavskoj Reči”. Treść tej instrukcji znajduje się w Instytucie Józefa Piłsudskiego w Ameryce (delej: IPA), w zespole Adiutantury Generalnej. Według Andrzeja Nowaka głównym zadaniem gazety było przekonanie ludności o nieuchronności kontroli polskiej nad Kresami, A. Nowak, op. cit., s. 489. Por. W. Stanisławski, op. cit., s. 261.

${ }^{35}$ AAN, TSK, sygn. 465, k. 2-3; „Biuletyn Bibliograficzny”, r. I, nr 2, s. 46.

${ }^{36}$ AAN, TSK, sygn. 408, k. 17.

${ }^{37}$ Ibidem, k. 18. 
stosunków polsko-rosyjskich ${ }^{38}$. Rzeczywiście, już w 1919 r. Naczelnik zastanawiał się nad alternatywą w stosunku do bolszewików i ,białych”,39, a od stycznia 1920 r., za pośrednictwem głównie Karola Wędziagolskiego, rozpoczął z nim negocjacje słynny terrorysta, członek Partii Socjalistów-Rewolucjonistów Boris Savinkov oraz jeden z przywódców partii eserowców Nikolaj Čajkovski ${ }^{40}$. Rosyjscy goście, podniesieni na duchu słowami Żeligowskiego, rozpoczęli cykl wykładów w Mińsku oraz nawiązali, mimo złej opinii, jaką się cieszył, współpracę z Gzowskim ${ }^{41}$, który ochoczo udostępnił im strony swojego dziennika. Tam dali się poznać jako przyjaciele Polaków: „Kiedy Dima po raz pierwszy wydrukował u Gzowskiego, że osławione granice z 72. roku to tylko sprawiedliwość — było tak, jakbyśmy podpisali się pod tym wszyscy. Dima napisał nawet, że plac Saski w Warszawie byłby ładniejszy bez soboru — pomnika rosyjskiego samodzierżawia — i że należałoby go zburzyć" ${ }^{42}$. Owa trójka: Merežkovski, Gippius i Filosofov, walnie przyczyniła się do upowszechnienia idei „trzeciej Rosji”, której hasło oficjalnie rzucił latem $1920 \mathrm{r}$. Savinkov ${ }^{43}$. W drodze do Warszawy zatrzymali się w Wilnie, gdzie nieprzypadkowo zostali przyjęci przez Wańkowicza, przypomnijmy - kierownika Wydziału Prasowo-Wydawniczego TSK, odpowiadającego również za kontakty z Rosjanami. Od przełomu kwietnia i maja trwały zabiegi o utworzenie nowej gazety rosyjskiej ${ }^{44}$, które zakończyły się wraz z wydaniem pierwszego numeru dziennika „Svoboda” 17 VII 1920 r. Był to organ Rosyjskiego Komitetu Politycznego (dalej: RKP), którego oficjalnym redaktorem został Žlobin, natomiast faktycznym Gzowski; Gippius kierowała działem propagandy. Pisali do niej Filosofov, Merežkovski, Savinkov, Nikolaj Bulanov, Boris Hêršêlman, Dmitrij Odiniec. Rosjanie otrzymali wsparcie zarówno polityczne, jak i materialne. W początkowym okresie potraktowano ich zgodnie z wcześniejszymi doświadczeniami, narzucając im nieoficjalnego polskiego redaktora. Niemniej nie było to typowe pismo inspirowane przez władze polskie, gdyż to Rosjanie sami zabiegali o jego utworzenie, decydując się m.in. na uznanie przedrozbiorowych granic Polski z 1772 r. i ustawiając siebie w roli siły politycznej zorientowanej na Polskę, z której pomocą wiązali nadzieje na objęcie władzy w Rosji ${ }^{45}$. Mimo klęski „trzeciej Rosji” i opuszczenia Polski przez większość współpracowników Savinkova polskie władze dalej wspierały „Svobodu” przemianowane na „Za Svobodu!”, a w szczególności jednego z jej publicystów Filosofova, byłego zastępcę Savinkowa w RKP, mają-

\footnotetext{
${ }^{38}$ Z. Gippius, op. cit., s. 448, 449.

${ }^{39}$ Nie wprost świadczą o tym wielokrotnie przytaczane przez historyków słowa Naczelnika wypowiedziane w wywiadzie dla „Le Matin” z 15 II 1920 r.: „Nie sposób jest dawną Rosję powołać ponownie do życia, za wszelką cenę, przy pomocy dawnych jej ludzi. Należy szukać nowych formuł [...] trzeba mieć odwagę zrozumienia, że na wschodzie Europy zaszła olbrzymia zmiana [...] Opracowujemy więc obecnie plan, mający na celu stworzenie legalnego stanu rzeczy na wschodzie Europy”, J. Piłsudski, Pisma zbiorowe, t. V, Warszawa 1937, s. 148.

${ }^{40}$ K. Wędziagolski, Pamiętniki, Warszawa 2007, s. 393, 394; A. Nowak, op. cit., s. 458, 462.

${ }^{41}$, ,Gzowski] to moskiewski Polak, niegdyś niewiele znaczący reporter, który tułał się po rozmaitych redakcjach. Za bolszewików pracował w bolszewickiej gazecie, możliwe że szpiegował dla Polaków (w razie czego, mógłby to robić także w drugą stronę). Olbrzymiego wzrostu, z tubalnym głosem, wyjątkowy cham, nigdy takiego w życiu nie widziałam", Z. Gippius, op. cit., s. 444.

42 Ibidem, s. 446.

${ }^{43}$ A. Nowak, op. cit., s. 486.

${ }^{44}$ „Deklaracja D. Mereżkowskiego, D. Filosofowa, B. Herszelmana i N. Bułanowa w sprawie wydania nowego pisma rosyjskiego w Warszawie, b.d. (kwiecień-maj 1920 r.)”, A. Nowak, op. cit., s. 490, przyp. 97.
}

${ }^{45}$ A. Nowak, op. cit., s. 490. 
cego przemożny wpływ na materiały publikowane w tym piśmie, jednak będącego jego oficjalnym redaktorem dopiero od $1925 \mathrm{r}^{46}$

Poza wspomnianymi pismami kontrolowanymi przez TSK i Oddział II w 1920 r. wychodziły: efemeryczne „Varšavskoe Utro” pod redakcją Michała Usmana, byłego pracownika „Varšavskoj Reči”; „Zarevo Revolucji” — organ Rosyjskiego Komitetu Anarchistów-Rewolucjonistów; „Poslednaâ Pravda” oraz satyryczna „Osa”, wszystkie bez większego znaczenia $^{47}$. Wyjątek stanowiło „Novoe Varšavskoe Slovo”, które założył, nieskrępowany już umową, Horvitz - pierwszy numer ukazał się 30 IX 1920 r. Tym samym można stwierdzić, że w 1920 r. na terenach objętych polską władzą większość informacji, które docierały do rosyjskojęzycznej ludności Polski, pochodziły z pism będących głównie pod kontrolą organów państwowych $^{48}$.

Inspiracja prasy rosyjskiej nie mogła ujść uwadze WCzK oraz niektórych bacznych obserwatorów z grona „emigrantów” znajdujących się w Polsce. Szczególnie aktywność agentury bolszewickiej sprawiała, iż każde nawiązanie współpracy z rosyjską redakcją groziło dekonspiracją przedsięwzięcia, ujawnieniem metod działania lub penetracją przez obcy wywiad. Przykładem takiego agenta był Horvitz-Samojlov, po raz pierwszy publicznie zdemaskowany przez redaktora Nowickiego. Z jego gazety dowiadujemy się, że na przełomie lipca i sierpnia 1919 r. Horvitz, będący zresztą od początku swego pobytu w Warszawie pod obserwacją policji politycznej, tzw. defensywy ${ }^{49}$, został aresztowany pod zarzutem szpiegostwa ${ }^{50}$. Co więcej, jego korespondencja z majorem Oddziału II SG Mieczysławem Domańskim miała być przyczyną aresztowania tegoż ${ }^{51}$. Budzi to jednak wątpliwości — sam major twierdził, że nie postawiono mu zarzutów, trzymając go w więzieniu od 23 VIII 1919 do 2 V 1920 r.,

${ }^{46}$ I. Obłąkowska-Galanciak, Gorzkie gody... Publicystyka i literacka działalność Dymitra Fiłosofowa na emigracji, Olsztyn 2001, s. 187, 188.

47 „Biuletyn Bibliograficzny”, r. I, nr 3, s. 35, nr 4, s. 46.

${ }^{48}$ Zgodnie z „Biuletynem Bibliograficznym” sporządzanym przez Wydział Prasowy MSW do 30 XII 1920 r. ocenzurowano spośród wszystkich czasopism rosyjskich tylko jeden numer „Varšavskogo Slova” oraz kilka numerów czasopisma o lokalnym zasięgu „Prikarpatskaâ Ruś” (organ rosyjskiego Komitetu Wykonawczego we Lwowie), ,Biuletyn Bibliograficzny”, r. I, nr 3, s. 42, nr 4, s. 49.

${ }^{49} \mathrm{Z}$ raportu dowiadujemy się, że Horvitz był byłym urzędnikiem 27 Korpusu, który uniknął rozstrzelania dzięki bolszewikowi Mikołajowi Grojnemowi, pełniącemu wtedy funkcję naczelnika głównego Zarządu Wojskowych Zakładów Naukowych, w którym zatrudnił go jako naczelnika wydziału; na początku 1919 r. wyjechał do Warszawy, AAN, MSW, sygn. 1195, k. 364.

50 „Russkoe Eho”, nr 14 i 16 z 27 i 29 VIII 1919. Przemawia za tym fakt, iż wydawana przez niego gazeta „Svobodnoe Slovo” przestaje wychodzić w drugiej połowie lipca $1919 \mathrm{r}$.

${ }_{51}$ Aresztowanie mjr. Domańskiego, jak twierdził Juzwenko, mogło wpłynąć na opóźnienie wyjazdu misji gen. Aleksandra Karnickiego do gen. A. Denikina na Krym; co więcej, kandydatura mjr. Domańskiego była również rozpatrywana wcześniej, przy formowaniu składu misji do adm. Aleksandra Kołczaka, A. Juzwenko, op. cit., s. 175, 176, 240, DiM, t. II, s. 307. Aresztowanie przekreśliło karierę dobrze zapowiadającego się specjalisty od zagadnień rosyjskich, który nie tylko miał uczestniczyć z ramienia Oddziału II SG w negocjacjach z Rosjanami, lecz przez mniej więcej miesiąc zdążył być szefem Oddziału VI, na którym to stanowisku w kwietniu 1919 r. zastąpiony został przez mjr. Karola Bołdeskuła, R. Czarnecka, Organizacja Oddziału II Sztabu Generalnego WP (Sztabu Głównego) i jego ekspozytur terenowych w latach 1918-1939, w: Wywiad i kontrwywiad wojskowy II RP, red. T. Dubicki, Łomianki 2010, t. I, s. 11. Michał Kossakowski zanotował, iż został on aresztowany za szpiegostwo, ponadto utożsamił go z Aleksandrem Jabłonowskim, publicystą „Reči” w latach 1915-1918 (autorowi nie udało się odnaleźć tej gazety), co mogłoby tłumaczyć jego kontakty z warszawskim środowiskiem prasowym, M. S. Kossakowski, Diariusz, t. IV, cz. 2, s. 92, 157, APAN, Michał Stanisław Kossakowski, sygn. 4 , j. 15. 
zakazując jednocześnie powrotu do służby ${ }^{52}$. Natomiast Horvitz znalazł się na wolności już na początku listopada 1919 r. W tym czasie sprzedawał on TSK prawa do prowadzonych przez siebie tytułów prasowych. Z braku odpowiednich materiałów nie możemy być pewni, czy oba aresztowania rzeczywiście miały ze sobą związek, lecz wydaje się, iż w obu przypadkach nie było wystarczających dowodów do postawienia zarzutów. Możliwe, że aresztowanie Horvitza oraz jego długi ułatwiły TSK nawiązanie z nim współpracy. Nie wiadomo, czy podjęto wtedy próbę przewerbowania go, czy też, mimo jego agenturalnej tożsamości, postanowiono go wykorzystać do własnych celów. Według Kočika praca dziennikarska służyła Horvitzowi jedynie za przykrywkę, jako nielegał miał on pozyskać m.in. wojskowe umowy polsko-rumuńską oraz polsko-francuską ${ }^{53}$. Dodatkowo jego publicystyka była zorientowana na osłabianie wpływów „białych” oraz wewnętrzne skonfliktowanie środowiska emigracyjnego w celu sparaliżowania jego inicjatyw, czego apogeum stanowiła próba obalenia legalnych władz Komitetu Rosyjskiego ${ }^{54}$. Wszystko wskazuje no to, że Oddział II oraz TSK dostrzegały jedynie ten aspekt jego agenturalnej pracy. Pod koniec 1919 r. udało im się zneutralizować Horvitza jako wydawcę, lecz nie jako agenta, który mógł mieć kontakty w Sztabie Generalnym oraz w Ministerstwie Spraw Wewnętrznych ${ }^{55}$. Należy również pamiętać, że struktury polskiego wywiadu i kontrwywiadu, zarówno cywilnego, jak i wojskowego, formowały się okresie bardzo specyficznym - wojennym, pełnym zamieszania, zmian, ogromnej dynamiki, dużych migracji ludności. Składały się z różnych oficerów, mających odmienne doświadczenie lub jego brak, którzy natychmiast zostali rzuceni w wir pracy, co stwarzało większe ryzyko popełnienia błędu oraz przeoczenia czegoś ${ }^{56}$. W 1924 r. Horvitz, pseudonim Iwanow, został namierzony przez wywiad czechosłowacki, lecz uniknął aresztowania, po czym ślad po nim zaginą ${ }^{57}$. Faktem jest, iż do tego czasu prowadził aktywną działalność agenturalną, w tym do 1923 r. w Polsce. Niestety, bez dostępu do materiałów, na które powoływał się Kočik, nie będziemy w stanie zweryfikować jego rewelacji, nie mając pewności, czy nie mamy do czyniania z hagiografią kolejnego sowieckiego nielegała.

Doprowadzając narrację do października 1920 r., trzeba zadać pytanie, jakie były efekty polskich działań. Według informacji pochodzących zarówno z najwyższych kręgów wojskowych, jak i od działaczy terenowych TSK prasa rosyjska wywoływała pożądany dla państwa

\footnotetext{
${ }_{52}$ IPA, AGNW, t. 701/2/12, k. 441-443.

${ }_{53}$ W. Kočik, Razvedčiki i rezidenty GPU za predelami otčiznyj, Âuza 2004, s. 469, http://m.tululu.org/ bread_55558_469.xhtml (dostęp: 2 I 2015).

${ }_{54}$ „Svobodno Slovo”, nr 87, 14 VII 1919.

55 „Резидент ИНО в Вене «Черский» (Э. С. Гольденштейн) писал 18 апреля 1924 года, что Самойлов «в период своей деятельности в Польше нашел источники информации в министерствах и польской дефензиве. Результаты его деятельности в тот период характеризуются как очень хорошие» (РГВА. Ф. 308к. Оп.9. Д. 1973. Л.76.)”, W. Kočik, op. cit., s. 469.

${ }_{56}$ Wacław Solski, znany komunista, wspominał, iż udało mu się ukryć przez pewien czas w Wojsku Polskim, a innym razem gdy został aresztowany, natychmiast go zwolniono, gdyż przed przesłuchaniem spotkał swojego kolegę z klasy, który obecnie pracował w defensywie, W. Solski, Moje wspomnienia, Warszawa 2008, s. 191, 193. Ciężkie warunki oraz brak profesjonalizmu pracowników Oddziału II wspominał Stanisław Z. Zakrzewski, Na wozie i pod wozem, Warszawa 2010, s. 191, 192. Jakkolwiek byłyby to subiektywne opinie, przybliżają one nie tyle konkretne fakty, ile ogólny klimat pracy w pierwszych latach niepodległości. W ocenie Andrzeja Pepłońskiego kontrwywiad ustępował pod względem kwalifikacji wywiadowi, A. Pepłoński, Wywiad w wojnie polsko-bolszewickiej1919-1920, Warszawa 1999, s. 296, 297.

${ }^{57}$ Ibidem, s. 471, http://m.tululu.org/bread_55558_471.xhtml (dostęp: 2 I 2015).
} 
polskiego efekt ${ }^{58}$. Musiał być on jednak krótkotrwały, gdyż wraz z przerwaniem frontu oraz szybkim odwrotem polskich armii spod Mińska i Kijowa zaprzestano wydawania prasy na zajętych przez bolszewików terenach. Szybki odwrót wojsk polskich podważał wiarę mieszkańców opuszczonych ziem w ich przynależność do państwa polskiego. A nawet gdyby do niego nie doszło, potrzeba byłoby wielu lat, by owa operacja dała pozytywne efekty. Na pewno udało się doraźnie przygłuszyć wpływy bolszewików oraz „białych”, lecz dla wielu uchodźców sympatyzujących z „,białymi” Horvitz-Samojlov firmujący polskie inicjatywy był osobą podejrzaną - zarówno ze względu na bolszewizujące poglądy, współpracę z Polakami, jak też żydowskie pochodzenie ${ }^{59}$. Niemniej trzeba podkreślić, że adresatem prasy była ludność rosyjskojęzyczna Kresów, a nie ówczesne elity rosyjskie przebywające w Polsce.

Jak zwróciła uwagę Joanna Gierowska-Kałłaur, „[...] Straż Kresowa wyrażała kierunek Józefa Piłsudskiego i Naczelnego Dowództwa WP, stojąc na gruncie Odezwy Wileńskiej" ${ }^{60}$. Dotyczyło to również polityki Naczelnika wobec zarówno „białej”, jak i „trzeciej” Rosji, realizowanej również poprzez inspirację prasy. Paradoksalnie, gdyż kłóciło się to z innymi instrukcjami dla tejże gazety, jako pierwsze miało głosić istnienie demokratycznej Rosji „Varšavskoe Slovo",61. Pojawienie się Rosyjskiego Komitetu Politycznego w Warszawie spowodowało ostateczne zamknięcie „Slova” i wzmocnienie przekazu dotyczącego budowy „trzeciej”, demokratycznej Rosji. Tymi słowami można by zamknąć bilans zysków i strat płynących z inspirowania lub współpracy z Rosjanami, gdyby nie zagadkowa sprawa HorvitzSamojlova, który prowadził swoją działalność, maskując ją pracą dziennikarską, i to pod bokiem polskiego wywiadu.

\section{Inspiracja pism zagranicznych}

Po pierwszych doświadczeniach w inspirowaniu pojedynczych tytułów prasowych w Oddziale II SG pojawił się pomysł stworzenia całej agencji prasowej, która bez podejrzeń mogłaby informować setki rosyjskich tytułów prasowych w całej Europie. W tym celu na kierownika owej agencji starano się wybrać osobę niezaangażowaną politycznie w działania żadnego ze stronnictw emigracyjnych ${ }^{62}$. Wybór padł na Sergeâ Kelniča ${ }^{63}$, który został szefem

\footnotetext{
${ }^{58}$ Instruktor TSK o dużym popycie w pow. rówieńskim na „Ogoniok”, AAN, TSK, sygn. 465, k. 3. Sztab Ścisły miał zażądać kolportowania gazety „Varšavskoe Slovo” w Kijowie, J. Gierowska-Kałłaur, op. cit., s. 20.

${ }^{59}$ Apel oficerów rosyjskich o nieczytanie dziennika „Svobodne Slovo”, „Eho”, nr 1, 15 VII 1919;

Z. Gippius, op. cit., s. 459. Por. A. Nowak, op. cit., s. 489.

${ }^{60}$ Ibidem, s. 18.

${ }^{61}$ Przypomnijmy, że gazeta miała krytykować zarówno bolszewików, reakcję, jak i zdolność do budowy państwa demokratycznego. „Jednocześnie «Warszawskoje Słowo» miało «wywiesić hasło federacji wolnej demokratycznej Rosji z wolną demokratyczną Polską». W kontekście wcześniej wymienionych założeń, ostatnie to hasło nie brzmiało zbyt przekonywająco [...]”, A. Nowak, op. cit., s. 489.

${ }^{62}$ Według cytowanych przez W. Stanisławskiego dokumentów O II z CAW agencja miała kierować się następującymi zasadami: „ «Aby nie podzielić losów różnych ajencji agitacyjnych, które zwykle nie cieszą się zaufaniem prasy, postanowiono w swej pracy kierować się zupełną bezpartyjnością, nie nawiązywać stosunków z żadnym ugrupowaniem politycznym i dawać informacje najzupełniej obiektywne, nacechowane jedną tylko tendencją — antybolszewicką)”, W. Stanisławski, op. cit., s. 264.

${ }^{63}$ Sergej Mihajlovič Kelnič (ok. 1890-1969) — warszawski dziennikarz, nauczyciel i księgarz; w czasie wojny był wojennym korespondentem; w 1919 r. wyjechał do Odessy, gdzie pracował w gazecie „Prizyv” i kierował pismem „Syn Otečestva”; w lutym 1920 r. wrócił do Warszawy, gdzie w październiku założył agencję telegraficzną „Russpress” (informacje od niej pozyskiwało 420 europejskich gazet); w 1924 r. założył wydawnictwo i księgarnię; był korespondentem berlińskiego „Rulâ”; w latach
} 
Agencji Prasowej „Russpress”. Agencja, tak jak wcześniejsze inicjatywy prasowe, została utworzona przez figurantów Oddziału II, który łożył na jej funkcjonowanie od października 1920 r. do listopada 1922 r. ${ }^{64}$ Posiadała ona sześć oddziałów: berliński — kierowany przez Orečkina, redaktora pisma „Emigrantskâ Žyzn”, paryski, praski, czasowo sofijski, rewelski - kierowany przez Lwowa, redaktora „Poslednie Izvestiâ”, i ryski. Planowano stworzenie również oddziału belgradzkiego, kiszyniowskiego, kopenhaskiego, londyńskiego, wiedeńskiego i kowieńskiego ${ }^{65}$. Do inspirowanych w krajach bałtyckich pism rosyjskich należy dodać jeszcze „Rižskij Kurier”, którego redaktor Donat Zaborovskij od grudnia 1920 r. do likwidacji w 1924 r. przyjmował polskie subsydia ${ }^{66}$. Sprawę funkcjonowania i zamknięcia pisma znamy z zachowanych akt Oddziału II w AAN, co daje możliwość przeanalizowania warsztatu dwójkarzy. Z początkiem 1923 r. powołano komisję w składzie: attaché kmdrpor. Bogdan Jarociński, mjr SG Władysław Sokołowski - szef Wydziału I Organizacyjnego, i kpt. SG Konrad Libicki — szef Referatu Prasy Obcej Wydziału I Organizacyjnego ${ }^{67}$, w celu oceny funkcjonowania gazety i jej dalszej przyszłości. Ocena wypadła pozytywnie: ,[...] Wydawnictwo to spełniło swe zadanie propagandowe w znaczeniu informacyjnem, podając Łotwie materiał w sprawach polskich, pochodzący z pierwszej ręki i dementując stale wszelkie fałsze, szerzone przez propagandę wrogą [...] inspirując stale i konsekwentnie opinię publiczną w zdecydowanym kierunku" "68 lecz mimo to zasugerowano stopniowe wycofanie się $z$ jej subsydiowania ${ }^{69}$, jak również likwidację specjalnie utworzonej drukarni. Zgodę na owe działania wydał szef Oddziału II, płk Ignacy Matuszewski ${ }^{70}$. Tak jak wszystkie inspirowane pisma rosyjskie było antybolszewickie, ale ponadto miało zwalczać wpływy innej ryskiej gazety — „Segodnâ”, która od początku przyjęła antypolską narrację. Z czasem zyskała ona jedną $z$ pierwszych pozycji na europejskim rynku prasy rosyjskiej ${ }^{71}$, wzbudzając zainteresowanie władz polskich, o czym w kolejnym rozdziale. Według Abyzova „Rižskij” nie cieszył się popularnością, w przeciwieństwie do „Segodnâ,,72, co może tłumaczyć jego szybkie zamknięcie po stopniowym zmniejszaniu subsydiów.

1924-1931 przedstawicielem i korespondentem „Segodnâ”, ps. „Dobrotin”; w połowie lat trzydziestych publikował w paryskim „Vozroždene”; w 1939 r. został korespondentem berlińskiej gazety „Novoe Slovo", ps. S. Moskvin, w 1944 r. znalazł się w zachodnich Niemczech, skąd wyjechał do Argentyny i tam pracował w rosyjskiej prasie, Russakâ pečat' w Rige: iz istorii gazety Segodnâ 1930-h godov, oprac. J. Abyzov, L. Flejšman, B. Ravdin, Stanford 1997, kn. I, s. 323.

${ }^{64}$ W. Stanisławski, op. cit., s. 264.

${ }^{65}$ Ibidem, s. 264.

${ }^{66}$ J. Abyzov, „Русские в Латвии. История и современность. Выпуск 2”, http://www.russkije.lv/ru/ pub/read/rus-in-latvia-edition2/abizov-rus-latvii-2.html (dostęp: 6 XII 2014). Badacz ten jest autorem licznych wartościowych publikacji z zakresu historii emigracji rosyjskiej.

${ }^{67}$ Informacja na temat członków Komisji zob.: R. Czarnecka, op. cit., s. 18; R. Majzner, Strukturalnoorganizacyjne aspekty funkcjonowania ataszatów wojskowych II RP. Zarys problematyki, w: Wywiad, s. 98 .

${ }^{68}$ AAN, Sztab Główny w Warszawie 1919-1939 (dalej: SG), sygn. 616/21, k. 5.

${ }^{69}$ „Komisja natomiast, proponuje pozostawić wolną rękę redakcji pisma co do kierunku z zastrzeżeniem utrzymania prądu antysowieckiego i nie współdziałania z propagandą niemiecką i litewską. W razie odmowy ze strony redaktora, Komisja proponuje stopniową likwidację R.K.”, AAN, SG, sygn. $616 / 21$, k. 5 .

${ }^{70}$ Ibidem, k. 6.

${ }^{71}$ Russakâ pečat', kn. I, s. 36, 110.

72 J. Abyzov, op. cit., http://www.russkije.lv/ru/pub/read/rus-in-latvia-edition2/abizov-rus-latvii-2.html (dostęp: 6 XII 2014). 
Do znanych nam pism dodamy jeszcze na koniec inspirowane prawdopodobnie od sierpnia 1920 r. do lutego 1921 r. „Poslednie Izvestâ” w Rewlu ${ }^{73}$. Świetnie rozwijająca się operacja Oddziału II została zdekonspirowana w 1922 r. przez emigranta-renegata Vadima Belova, który podjął współpracę z WCzK i w pracy „Belaâ Pečat” ujawnił, że Polska spośród wszystkich państw limitrofów najintensywniej subsydiowała prasę rosyjską, czego przykładem miały być „Svobodu”, „Rižskij Kurier” i „Poslednie Izvestâ,74.

\section{Inspiracja pism krajowych}

W tym miejscu skupimy się jedynie na dwóch najlepiej znanych, lecz różnych w swoim charakterze pismach: „Volynskoe Slovo” (1922-1929) i „Novaâ Rossiâ” (1926-1927). Redaktorem pierwszego był Izmail Černov, od początku współpracujący z Oddziałem II. Pismo początkowo miało być narzędziem oddziaływania na mieszkańców ZSRS, lecz z czasem jego głównym zadaniem stała się propaganda propaństwowa ${ }^{75}$. Interesujące, że pismo, mimo dużego nakładu — do 50000 (większość pism rosyjskich wychodziło w małych nakładach) — i długiego okresu funkcjonowania nie zostało zdekonspirowane. Według swoich mocodawców świetnie spełniało wyznaczoną rolę, gdyż do końca nikt się nie domyślał źródeł jego powstania. Ponadto było darzone zaufaniem przez monarchistów rosyjskich, co skusiło wywiad do podsunięcia go, poprzez jednego z jego pracowników, Rosyjskiemu Komitetowi Narodowemu w Paryżu, najwyraźniej bez powodzenia ${ }^{76}$. Nie wiadomo, dlaczego pismo zostało zamknięte. Można wysunąć trzy hipotezy. Pierwsza wiąże się z niechęcią wojewody wołyńskiego Henryka Józewskiego do jakichkolwiek inicjatyw rosyjskich, a przecież „Slovo” walczyło z ukrainizacją Cerkwi. Druga związana jest ze wsparciem, jakie pismo udzieliło Rosyjskiemu Zjednoczeniu Ludowemu Nikolaâ Serebrânnikova, który w tym czasie tracił poparcie MSW. Trzecią być może należy powiązać z zamachem na szefa sowieckiej misji handlowej Alekseâ Lizareva w maju 1928 r., po którym zdecydowano się na dość ostre represje W stosunku do środowiska emigracyjnego ${ }^{77}$.

Drugie czasopismo zostało utworzone przez Mihaila Jakovleva, agenta Ekspozytury nr 1 W Wilnie ${ }^{78}$. „Novaâ Rossiâ” była najbardziej propolskim spośród emigracyjnych czasopism. $\mathrm{Na}$ jej łamach Jakovlev wielokrotnie nawoływał do współpracy polsko-rosyjskiej ${ }^{79}$, wskazywał na antybolszewickie „właściwości” Cerkwi ${ }^{80}$, stawiał Polaków za wzór do naśladowania $^{81}$. Nawet w przypadku wysiedleń rosyjskich emigrantów, po zamachu na posła Wojkowa, kiedy większość Rosjan zaniepokoiła się tym wydarzeniem, Jakovlev uspokajał, że nie wszyscy emigranci zostaną wysiedleni, lecz tylko ci, którzy prowadzili działalność antypaństwo-

\footnotetext{
${ }^{73}$ W. Stanisławski, op. cit., s. 264, 265.

${ }^{74}$ Ibidem.

${ }^{75}$ W. Stanisławski, op. cit., s. 265. Przykładowo na łamach pisma wzywano do wpłacania składek na LOPP, „Volynskoe Slovo”, nr 993, 15 V 1926; dużo miejsca poświęcono wizycie prezydenta Ignacego Mościckiego na Wołyniu, „Volynskoe Slovo”, nr 1435, 20 VI 1929.

${ }^{76}$ Cyt. za: W. Stanisławski, op. cit., s. 266, przyp. 186.

${ }^{77}$ Możliwe, że o jego zamknięciu zdecydowało kilka czynników. Należy również podkreślić, że władze wojewódzkie najwyraźniej nie wiedziały, że jest on agentem Oddziału II, gdyż w 1927 r., po zamachu na połpreda Piotra Wojkowa, znalazł się on wśród aresztowanych działaczy monarchistycznych, AAN, Urząd Wojewódzki w Łucku, sygn. 55, k. 64-65.

${ }^{78}$ A. Pepłoński, Wywiad polski na ZSRR 1921-1939, Warszawa 1996, s. 244.

79 Rossiâ i Polša, „Novaâ Rossiâ”, nr 45, 2 X 1927, s. 1.

${ }^{80}$ Ibidem, nr 29 z 10 IV 1927, s. 4.

${ }^{81}$ M. Jakovlev, Nacionalnyj Prazdnik, „Novaâ Rossiâ”, nr 30, 15 V 1927, s. 1.
} 
wą. Do tych, jak twierdził, należą wysiedleni z Wilna A. Romašev, były redaktor „Utra”, określony mianem intryganta i sympatyka Żydów, V. Adamovič, rzekomy ataman „Derkacz”, przywódca „Zielonego Dębu" ${ }^{, 82}$. Redakcja była do tego stopnia podporządkowana władzom polskim, że w wyborach do Sejmu z 1928 r. nawoływała do głosowania na Stanisława Mackiewicza, jednocześnie listę rosyjską nazywając „,niepotrzebną demonstracją "83. Czy taka propaganda była skuteczna? Niestety, nie mamy na ten temat informacji, choć trzeba zaznaczyć, że miała specyficzny charakter. Jej adresatem byli emigranci, w szczególności żołnierze rosyjscy z byłych formacji antybolszewickich walczących po stronie polskiej, którzy z różnych przyczyn zdecydowali się pozostać w Polsce. Być może autorytet redaktora naczelnego oraz części pracowników, rekrutujących się zapewne z byłych wojskowych, odgrywał tutaj dominującą rolę. Funkcjonowanie gazety było częścią szerszego planu, mającego na celu przeciwdziałanie propagandzie bolszewickiej w ich szeregach oraz konsolidacji wokół obozu rządzącego (postawa byłych żołnierzy rosyjskich była nie bez znaczenia ze względu na system obronny Kresów). Pismo zostało zamknięte wraz z wysłaniem Jakovleva na placówkę wywiadowczą do Francji w 1928 r. $^{84}$

\section{Próby utworzenia „koncernu” prasowego? — rola Dimitrâ Filosofova}

Na przełomie lat dwudziestych i trzydziestych władze polskie miały szansę przejąć kontrolę nad kilkoma dużymi czasopismami rosyjskimi, równolegle podejmując próbę konsolidacji mniejszości i emigracji rosyjskiej wokół państwa i obozu rządzącego. Nim przejdziemy do szczegółów tej operacji, zatrzymajmy się przez chwilę przy osobie Dimitrâ Filosofova, będącego zwornikiem tych działań. Latem 1920 r. został on zastępcą Savinkova w Rosyjskim Komitecie Politycznym (Русский политический комитет) oraz wiceprezesem Towarzystwa Polsko-Rosyjskiego kierowanego przez Władysława Tyszkiewicza ${ }^{85}$. Po zawarciu rozejmu między Polską a Rosją bolszewicką, w przeciwieństwie do swoich przyjaciół Gippius i Merežkovskiego, nie wyjechał do Paryża. Choć nie zerwał z nimi kontaktu, ich polityczne drogi nigdy już się nie zeszły ${ }^{86}$. Warto zacytować słowa Józefa Czapskiego, z których wynika, że decyzja o pozostaniu w Polsce została podjęta jeszcze przed rozstrzygnięciem bitwy warszawskiej: „To był Rosjanin, dla którego Trzecia Rosja i Polska mogłyby uratować świat od komunizmu. [...] Filosofow powiedział, że zostanie i został przez całą wojnę, kiedy w każdej chwili bolszewicy mogli wejść. Na nocnym stoliku zawsze miał truciznę"87. Współpraca z Savinkovem ${ }^{88}$ oraz stosunek do Polski po zawarciu przez nią rozejmu z bolszewikami oddalały Filosofova od Merežkovskich, którzy oburzeni na Piłsudskiego udali się do Paryża. Gippius sarkastycznie pytała Dimitrâ: „Czyżbyś zamierzał być pierwszym rosyjskim męczennikiem za sprawę Polski?" ${ }^{89}$. On natomiast ,[...] przesiąkł na wskroś romantyką no-

\footnotetext{
82 Idem, K vyseleniû russkih emigrantov iz Polši, „Novaâ Rossiâ”, nr 41, 28 VIII 1927, s. 3.

83 AAN, MSW, sygn. 958, k. 49.

${ }^{84}$ A. Pepłoński, op. cit., s. 244.

${ }^{85}$ K. Wędziagolski, op. cit., s. 388, 421.

86 Z. Gippius, op. cit., s. 465.

87 J. Czapski, Świat w moich oczach, Ząbki-Paris 2001, s. 43, 44.

88 „Pamiętam, jak wychodził z pokoju i mówi: «No jakże, ja bym wolał pracować politycznie z Czapskim niż z Sawinkowem». Nie byli więc intimes, ale politycznie się związali”, J. Czapski, Świat, s. 143. ${ }^{89}$ P. Mitzner, Warszawski, s. 15. Oboje namawiali go do opuszczenia Polski, zob. listy Gippius z października 1920 r. oraz Merežkovskiego z 11 III 1921 r. do Filosofova, „Наше Наследие” 2002, nr 63-64, http://www.nasledie-rus.ru/podshivka/6407.php (dostęp: 14 I 2015).
} 
wej ery w stosunkach polsko-rosyjskich"90. Mimo chwilowego przymusowego wyjazdu do Jugosławii $^{91}$ pozostał w Polsce, by dalej prowadzić walkę z bolszewikami na łamach stronic prasowych „Za Svobodu!”, a następnie „Molvy” i „Meča”"92. W latach 1921-1924 był kierownikiem polskiego oddziału Narodowego Związku Obrony Ojczyzny i Wolności (Народный Союз защиты родины и свободы), założonego przez Savinkova. Organizacja powstała za przyzwoleniem Oddziału $\mathrm{II}^{93}$, opanowanego w dużej mierze przez piłsudczyków, i funkcjonowała do 1924 r., do momentu otrzymania przez Filosofova listu Savinkova napisanego z Łubianki, wzywającego do uznania władzy Związku Sowieckiego ${ }^{94}$. Po otrzymaniu pisma Filosofov zaniósł je do Sulejówka i jednocześnie na łamach „Za Svobodu” odciął się od Savinkova $^{95}$, dzięki czemu nie utracił zaufania Marszałka ${ }^{96}$.

Rosjanie z kręgu Savinkova z entuzjazmem przywitali zwycięstwo Piłsudskiego w maju 1926 r. Od tego momentu datuje się również uaktywnienie polityczne całej społeczności rosyjskiej, co zamierzały wykorzystać nowe władze państwowe. W oczach obozu rządzącego najbardziej zaufaną i wpływową osobą był Filosofov, który już na początku swojego pobytu w Polsce zdążył poznać dużą część bliskich współpracowników Piłsudskiego, wielu profesorów, członków elity kulturalnej, a także polityków i wojskowych innych narodowości byłego imperium, jak Ukraińcy, Białorusini czy Gruzini. Wreszcie, co było najważniejsze z punktu widzenia Polaków, nie był on ich agentem, lecz sprzymierzeńcem, którego ideą od 1919 r. była budowa demokratycznej Rosji w oparciu o Polskę — co jednak przysparzało mu wielu wrogów wśród emigracji i prowadziło do jego izolacji w międzynarodowym ruchu emigracyjnym (mimo to w jego inicjatywach prasowych brali udział światowej sławy pisarze rosyjscy). Niemniej pełnił on bardzo ważną rolę w społeczeństwie rosyjskim w Polsce, skupiając wokół siebie byłych savinkovców, sporą część młodzieży oraz najlepszych literatów. Większość z nich współpracowała z „Za Svobodu” będącą jednocześnie najlepszą oraz najdłużej wydawaną (1920-1932) gazetą rosyjską.

Wszystko to zadecydowało, że konsolidacja emigracji rosyjskiej wokół państwa polskiego miała się dokonać we współpracy z Filosofovem i jego otoczeniem. W tym celu w $1931 \mathrm{r}$. powołano Rosyjski Komitet Społeczny (Российский Общественный Комитет в Польше) ${ }^{97}$.

${ }^{90}$ K. Wędziagolski, op. cit., s. 429.

${ }^{1}$ W liście z Jugosławii z 1921 r. pisał: „Mój pobyt w Polsce — to były moje lata najlepsze, robiłem to, co chciałem, a nie to, co mi się chciało", J. Czapski, Wyrwane strony, Warszawa 2010, s. 75.

${ }^{92}$ Osobiście motywował swoje pozostanie argumentem: „,...] przyszli historycy będą skłonni odczuwać naszą walkę z bolszewikami w kategoriach konfliktu pomiędzy Rosjanami i Polakami. Taka prosta dialektyka przedstawia fałszywie kręty i zawiły konflikt, który doprowadził do mojego postanowienia, aby pozostać w Polsce i walczyć obok Borysa Sawinkowa i Polaków [...]”, cyt. za J. S. Durrant, Borys Sawinkow w Warszawie - z pamiętników D. W. Fiłosofowa (artykuł oraz pamiętnik Moj Put' znajduje się w zbiorach Durranta), kopię mps. udostępnił autorowi prof. Andrzej Nowak.

${ }_{93}$ Pułkownik Matuszewski podkreślał jako szczególnie korzystne dla Polski destrukcyjną ideowo działalność Savinkova oraz deklarowanie przez niego „,...] rezygnacji z wielkomocarstwowej Rosji”, kwiecień 1921, Warszawa - Memoriał szefa Oddziału II Sztabu Generalnego WP I. Matuszewskiego w sprawie wykorzystania grup B. Savinkova i S. Pelury do akcji antyradzieckiej, DiM, t. IV, s. 15, 16; 19 VII 1921, Lwów - Raport Ekspozytury O II SG we Lwowie do Naczelnego Dowództwa WP zawierający zasady współpracy z agencją wywiadowczą B. Savinkova, DiM, t. IV, s. 27-30.

${ }_{94}$ J. Czapski, Świat, s. 143.

${ }_{95}$ List Filosofova do Savinkova z 16 IX 1924 r., http://www.nasledie-rus.ru/podshivka/6407.php (dostęp: 14 I 2015).

96 J. Czapski, Świat, s. 144.

${ }^{97} \mathrm{~S}$. Vojcehovskij opisywał powstanie komitetu, uważając, iż była to inicjatywa części emigrantów, lecz my uważamy, że mógł ją podsunął Filosofov po wcześniejszym uzgodnieniu kwestii z Hołówką, 
Jednocześnie starano się zmonopolizować prasę rosyjską poprzez doprowadzenie do porozumienia Filosofova, Kelniča (korespondent „Segodnâ”, szef agencji prasowej Russpres), Sergeâ Vojcehovskiego (korespondent „Segodnâ” oraz „Vozroždenie”) i Borisa Pimonova (poseł BBWR, przywódca staroobrzędowców), łącząc „Za Svobodu” (red. Dmitrij Filosofov) z wileńskim „Naše Vremâ” (red. Evgenij Kotlarevski) i ryskim „Segodnâ” (red. Mihail Milrud).

Plan nie został zrealizowany ze względu na splot różnych niekorzystnych faktów oraz jak się wydaje - brak koordynacji ze strony polskiej. Dlaczego nie doszło do połączenia „Za Svobodu” z subsydiowanym przez Pimonova „Naše Vremâ" ${ }^{98}$ ? Pimonow, podobnie jak Filosofov, prowadził propolską politykę, co więcej — został posłem z ramienia BBWR, a dzięki ówczesnemu ministrowi spraw wewnętrznych Bronisławowi Pierackiemu stał się przywódcą mniejszości rosyjskiej ${ }^{99}$. Otóż Filosofov był emigrantem, natomiast Pimonov członkiem mniejszości i obu różniły poglądy w stosunku do roli, jaką miało pełnić społeczeństwo rosyjskie w Polsce. Opór ze strony Pimonova zamknął również drogę do współpracy z „Segodnâ”, która wychodziła w Polsce jako dodatek do dziennika Kotlarevskiego ${ }^{100}$.

Próby pozyskania Kelniča trwały już od 1928 r., kiedy wsparcie finansowe dla utworzenia nowej dużej gazety rosyjskiej proponował ówczesny naczelnik Wydziału Wschodniego MSZ Tadeusz Hołówko ${ }^{101}$. Jednak Kelnič nie przepadał za Filosofovem ze względu na jego propolskie nastawienie i wolał współpracować z „Segodnâ” (o planach Filosofova oraz Vojcehovskiego informował Kelniča Georgij Šulgin, który ostatecznie opuścił redakcję „Za Svobodu" w 1931 r.) $)^{102}$. Być może planowano nawiązać również współpracę z paryskim „Vozroždeniem”, na co może wskazywać podróż Piotra Struvego na zaproszenie RKS do Polski w 1931 r. $^{103}$ oraz częstsze powoływanie się w „Za Svobodu” na artykuły z paryskiej

tym bardziej że niemal równolegle powstawała podobna organizacja mniejszości rosyjskiej, której Zjazd zainicjował Pimonov, opłacany przez MSW. „Был составлен меморандум, объясняющий наши намерения. Философов передал его начальнику восточного отдела министерства иностранных дел Тадеушу Голувко, [...] Русские эмигранты, с точки зрения международного нрава, были иностранцами, но Голувко признал, что существование их представительства будет полезно не только им, но и польской власти. Он убедил в этом министерство внутренних дел, утвердившее в 1931 году устав Российского Общественного Комитета в Польше. Его первым председателем стал Буланов, а одним из членов правления - Философов.”, S. Vojcehovskij, Epizody, LondonKanada 1978, http://www.dk1868.ru/history/voytzexov.htm\#z151 (dostęp: 14 I 2014).

${ }_{98}$ AAN. MSW, sygn. 85, s. 63, 64.

${ }^{99}$ AAN, MSW, sygn. 1074 (dopływ), k. 47-48. Dodajmy, że według wiceministra MWRiOP Bronisława Żongołłowicza był on opłacany przez naczelnika Wydziału Narodowościowego MSW Henryka Suchenka-Suchockiego, B. Żongołłowicz, Dzienniki 1930-1936, oprac. D. Zamojska, Warszawa 2004, s. 199.

${ }^{100}$ S. Kelnič do M. Milruda, Warszawa, 18 XII 1930, Russkaâ pečat’, kn. I, s. 329.

101 S. Kelnič do M. Milruda, 12 XII 1933, ibidem, kn. III, s. 160.

102 G. Mihajlovič Sulgin (1896-?) — ur. w Kijowie, dziennikarz; w 1931 r. opuścił redakcję „Za Svobodu” i został pracownikiem warszawskiego oddziału „Segodnâ”, a od 1932 r. członkiem warszawskiej redakcji „Naše Vremâ”; w 1943 r. zarejestrował się jako Volksdeutsch; pod koniec wojny trafił do obozu dla dipisów, Russkaâ pečat', kn. II, s. 175.

${ }_{103}$ Piotr Struve wygłosił odczyty w Warszawie, Wilnie i Grodnie, wyrażając nadzieję na dobrosąsiedzkie ułożenie stosunków między Polską a przyszłą Rosją. Na jego cześć zostało wydane śniadanie przez prof. Aleksandra Lednickiego, na którym byli liczni uczeni oraz naczelnik wydziału wschodniego MSZ Tadeusz Schaetzel, AAN. MSW, sygn. 85, s. 63, 64. Richard Pipes odnotował w kalendarium życia Struvego jedynie to, że w czerwcu-lipcu 1931 r. odbył podróż, odwiedzając Warszawę, Berlin i Pragę. Więcej miejsca poświęcił jego pierwszej wizycie w Polsce w czerwcu 1926 r., której oficjalnym celem 
gazety. Ów sojusz mógłby się wydawać zupełnie nierealny, lecz gdy przyjrzymy się bliżej poglądom Struvego, zrozumiemy, że była to osoba akceptowalna dla polskich władz - umiarkowanie pozytywnie nastawiona do rządów Piłsudskiego oraz wrogo wobec zarówno komunistów, jak i nazistów ${ }^{104}$. Niemniej wyprawa zakończyła się jedynie kilkoma pozytywnie przedstawiającymi Polskę artykułami na łamach „Vozroždeniâ”.

Czemu miała służyć owa polska ofensywa wśród Rosjan w Polsce oraz za granicą? Z pewnością poprzez podporządkowanie sobie trzech spośród kilku najbardziej wpływowych pism emigracyjnych czytanych w całej Europie, i to nie tylko przez Rosjan, władze polskie mogłyby zyskać doskonałe narzędzie propagandy. W działaniach tych nawiązywano zapewne do początku lat dwudziestych, kiedy to poprzez inspirowanie prasy rosyjskiej starano się wytwarzać nastroje przychylne wobec państwa polskiego na Kresach oraz w państwach bałtyckich. Na ile poważnie traktowano artykuły publikowane w najważniejszych rosyjskich periodykach, pokazuje przykład korespondenta „Segodnâ” Kelniča, wezwanego przez naczelnika Wydziału Wschodniego MSZ Tadeusza Schaetzela po opublikowaniu niekorzystnych dla Polski artykułów na temat zajść przed ambasadą litewską w Polsce i dotyczących polskiej mniejszości na Łotwie $^{105}$. O znaczeniu prasy rosyjskiej świadczą dążenia państw europejskich do zachowania wpływu na nią — „Rits” należał do spółki akcyjnej, w zarządzie której zasiadał gen. Jānis Balodis, „Rul” był wspierany przez niemiecki koncern wydawniczy, „Socialističeskij Vestnik” subsydiowany przez niemiecką partię socjaldemokratyczną, natomiast „Posledniâ Novosti” prawdopodobnie przez rząd czechosłowacki ${ }^{106}$. Niestety, brakuje nam materiałów, by się przekonać, jakie były pełne zamiary władz polskich i na ile była to skoordynowana akcja polskich instytucji. W tym przypadku najwięcej mogłyby wnieść akta Oddziału II, na chwilę obecną nieosiągalne. Pewne jest, że władzom polskim zależało na lojalnym tytule o zasięgu nie tylko ogólnopolskim, lecz ogólnoeuropejskim i jeśli nie inicjowali, to wspierali działania lojalnych Rosjan, takich jak Filosofov, o czym świadczy fragment wspomnień Vojcehovskego: Вероятно, не без помощи Голувки ему удалось получить согласие распространенной польской газеть „Экспресс Поран-ны”" на использование ее великолепных, только что доставленных из Дрездена ротационных машин, позволивших украсить газетные листы новинкой - цветнылми иллюстрациями ${ }^{107}$. „Mołva”, pierwszy ilustrowany dziennik Filosofova, skupił część środowiska demokratycznego oraz monarchistycznego w kraju; w swoje inicjatywy starał się również angażować emigrantów z Francji, Czechosłowacji, Włoch, Jugosławii, Bułgarii i Łotwy; najwięcej korespondował z Merežkovskimi, których nakłonił do współpracy przy redagowaniu „Meča”, i z Alfredem Bemem ${ }^{108}$. Na początku lat

było uczestnictwo w Międzynarodowym Kongresie Uczonych (kiedy to odbył krótką rozmowę z Piłsudskim), a rzeczywistym — chęć nawiązania kontaktu z polskim oddziałem Trustu w celu wyjaśnienia podejrzeń, jakie pojawiły się wokół tej organizacji, R. Pipes, Struve Liberal on the Right, 1905-1944, London 1980, s. 386-388, 465.

${ }^{104}$ Struve określił rządy pomajowe jako typ: demokratičeskoj diktatury. I êto novoe v svoem susestve âvlâetsâ zdorovym ispravleniem absolûtnoj parlamentskoj demokratii, P. V. Struve, Dnevnik Politika (1925-1935), Moskva-Pariž 2004; In other countries, he tended to favour «strong men» exemplified by Marshal Pilsudski, R. Pipes, op. cit., s. 412, 414.

${ }^{105}$ S. Kelnič do M. Milruda, Warszawa 24 X 1931 i 26 X 1931, Russkaâ pečat', kn. II, s. 170, 171.

106 Russkâ̂ pečat', kn. I, s. 176.

${ }^{107}$ S. Vojcehovskij, op. cit., http://www.dk1868.ru/history/voytzexov.htm\#z151 (dostęp: 14 I 2014).

${ }_{108}$ A. Bem (1886-1945), ur. w Kijowie, historyk literatury, krytyk literacki, działacz emigracyjny, współpracował z warszawskimi czasopismami „Za Svobodu!”, „Molva” i „Meč”, Sočineniâ russkogo perioda, t. I, red. L. Flejšman, Moskva 2011, s. 23. 
trzydziestych, prawdopodobnie za pośrednictwem Vladimira Branda ${ }^{109}$, nawiązał kontakt z działaczami NTS, których otwarcie popierał, ostatecznie przekazując im emigracyjną sztafetę w postaci „Meča”. Pismo to od 21 numeru stało się nieoficjalnym organem NarodowoPracowniczego Związku Rosyjskich Solidarystów (Народно-трудовой союз российских солидаристов), którego członkowie pozostawali w kontakcie z Oddziałem II ${ }^{110}$.

\section{Zakończenie}

Inspiracja oraz wspieranie lojalnej wobec państwa polskiego prasy odbywały się w sposób nieskoordynowany. Chcąc prześledzić od początku owe działania, trzeba wymienić przede wszystkim Straż Kresową, Oddział II SG, następnie Wydział Narodowościowy MSW oraz Wydział Wschodni MSZ, a w przypadku pism religijnych również MWRiOP. Urzędnicy i wojskowi z poszczególnych instytucji nie zawsze informowali się wzajemnie o swoich inicjatywach, co prowadziło czasami do omyłkowych aresztowań, a nawet spychania na siebie odpowiedzialności za koszty, z jakimi wiązało się inspirowanie prasy ${ }^{111}$. W grę wchodziły również tarcia między szefami resortów oraz wojewodami, którzy mieli rozbieżne koncepcje w stosunku do Rosjan, gdyż nie wypracowano w II Rzeczypospolitej spójnej, długofalowej koncepcji polityki wobec mniejszości ${ }^{112}$. Niemniej rezultaty inspiracji prasy rosyjskiej na ogół były zadowalające i nie zaprzestano ich do wybuchu wojny. Głównymi celami, jakie zazwyczaj stawiano subsydiowanej prasie, było zawsze zwalczanie propagandy bolszewickiej, podkopywanie wiary w wielkomocarstwową Rosję, osłabianie pozycji monarchistów, promowanie zwolenników demokratycznej Rosji, propaganda propaństwowa, dodatkowo dla prasy zagranicznej dementowanie szkodliwych dla Polski opinii oraz w przypadku tytułów takich jak „Volynskoe Slovo”, kolportowanych również do ZSRS, destabilizacja sytuacji.

Można wyróżnić kilka typów inspirowanej prasy. Pierwszy stanowiły tytuły prowadzone bezpośrednio przez agentów Oddziału II, drugi gazety, agencje, wydawnictwa zainicjowane przez figurantów, lecz prowadzone przez mniej lub bardziej świadomych współpracy Rosjan, trzecim tytuły prowadzone przez Rosjan, których pracę regulowały odpowiednie umowy; zazwyczaj odbywało się to również przez specjalnie stworzone spółki lub podstawionych akcjonariuszy. Do ostatniego typu, zapewne najwyżej cenionego, należały gazety, których kierownictwo współpracowało z organami polskiej władzy z powodów ideowych. Najlepszym przykładem było „Za Svobodu” oraz jej redaktor Filosofov pozostający w dobrych stosunkach z wieloma prominentnymi działaczami obozu piłsudczykowskiego. Należy przy tym

\footnotetext{
109 W. Brand (1892-1942), ppłk Armii Ochotniczej, członek Ludowego Związku Obrony Wolności i Ojczyzny, Bractva Russkoj Pravdy, „Tawerny Poetów”, a następnie grupy literackiej Литературное содружество, współpracownik „Za Svobodu!”, członek komitetu redakcyjnego „Molvy”; po odejściu Filosofova współredaktor naczelny „Meča”, będącego nieoficjalnym organem NTS, organizator tajnej szkoły dla działaczy NTS pod Warszawą, I. Gribkov, D. Žukov, Osobyj štab Rossiâ, Moskva 2011, s. 90; T. Ismagulova, Russkaâ emigraciâ v Polše (Vladimir Brand — poet $i$ woin „russkoj Waršavy”), w: Zarubežnaâ Rossiâ 1917-1939 gg. Sbornik stacej, red. V. J. Černâev, Sankt Peterburg 2010, s. 347-350.

110 B. Prânišnikov, Novopokolency, Maryland 1986, http://ntsrs.ru/content/glava-vii-nashi-gosti (dostęp: 14 I 2015); J. Divnič, NTS, nam pora obâsnicsâ!, New York 1968, s. 36; A. Stołypin, Cesarstwo i wygnanie, Warszawa 1998, s. 199, 200.

111 W. Stanisławski, op. cit., s. 266, przyp. 187.

112 A. Chojnowski, Koncepcje polityki narodowościowej rząów polskich w latach 1921-1939, Wrocław 1979, s. 240, 241.
} 
zaznaczyć, że nie był polskim agentem, lecz sojusznikiem, nigdy nie wyzbył się własnego zdania, publikując niemile widziane przez MSW artykuły, które niejednokrotnie obejmowano cenzurą. $Z$ drugiej jednak strony nie można się oprzeć wrażeniu, że część artykułów była po prostu zamawiana przez polskie ministerstwa, co mogło sprawiać wrażenie niekonsekwencji i wymagało dużej zręczności redakcji czasopisma, by nie stracić czytelników. W tym momencie dochodzimy do bardzo ważnego problemu, a mianowicie finansów, których brak był czasami, jak sądzę, decydującym argumentem do podjęcia chociaż przez pewien czas współpracy z Polakami.

Podsumowując, nie można zapomnieć o kwestii obcych agentów: niemieckich, „białorosyjskich", a szczególnie bolszewickich — od początku obecnych w inspirowanych przez Polaków pismach i obsadzających, według przypuszczeń autora, prawie każdą większą redakcję rosyjską w Polsce ${ }^{113}$.

Powyższy zarys, jak sama nazwa wskazuje, nie mógł pozwolić autorowi w sposób wystarczający wyłożyć wszystkich przypadków inspiracji prasowej. Tak samo jak nie daje ostatecznej odpowiedzi na pytanie, jaka była skuteczność owej działalności (jaki był odbiór inspirowanej prasy) w państwach europejskich, a w szczególności w Związku Sowieckim. Stosunkowo najłatwiej odpowiedzieć na pytania dotyczące kwestii wewnętrznych, gdzie rzeczywiście prasa rosyjska oddała przysługę państwu polskiemu oraz obozowi rządzącemu, który wykorzystywał ją jako narzędzie propagandy wśród rosyjskojęzycznych wyborców. W ocenie Wojska Polskiego, w tym Oddziału II, operacje inspiracyjne wypadały pozytywnie, lecz tak naprawdę nie wiadomo, na ile owa prasa przyczyniła się do wzmocnienia postaw nacechowanych lojalnością. Z pewnością zagospodarowała ona jednak sporą przestrzeń, którą mogłyby zapełnić pisma komunistyczne, i tak dość powszechnie kolportowane na Kresach.

Ze względu na liczne wątki, istotne z punktu widzenia polityki wewnętrznej, zagranicznej oraz obronnej II Rzeczypospolitej, które autor starał się zarysować w niniejszym artykule, temat inspiracji prasy rosyjskiej zasługuje na duży rozdział w studium poświęconym prasie lub społeczności rosyjskiej w Polsce.

Słowa kluczowe: emigracja, mniejszości, Rosjanie, Filosofov, polityka wewnętrzna, wywiad

\section{Bibliografia}

\section{Źródła opublikowane}

Czapski J., Świat w moich oczach, Ząbki-Paris 2001.

Czapski J., Wyrwane strony, Warszawa 2010.

Divnič J., NTS, nam pora obâsnicsâ!, New York 1968.

Piłsudski J., Pisma zbiorowe, t. V, Warszawa 1937.

Prânišnikov B., Novopokolency, Maryland 1986.

\footnotetext{
${ }^{113}$ Nawet tak przenikliwy demaskator bolszewickich agentów jak Filosofov prawdopodobnie nie ustrzegł się od nich i miał w swoim otoczeniu wtyczkę bolszewicką - Georgiâ Sokolova (18961976). Był on członkiem redakcji „Molvy” i „Meča”, w 1944 r. pozostał w Warszawie, mimo że mógł się ewakuować razem z innymi Rosjanami na Zachód; po wejściu Armii Czerwonej został wybrany „[...] председателем советофильского Русского Благотворительного Общества [...]”, w 1960 r. przewodniczący Zarządu Głównego Rosyjskiego Towarzystwa Kulturalno-Oświatowego w PRL, S. Vojcehovskij, op. cit., http://www.dk1868.ru/history/voytzexov.htm\#z151 (dostęp: 14 I 2014); P. Mitzner, Warszawski „Domek w Kolomnie”, Warszawa 2014, s. 59.
} 
Raporty Straży Kresowej 1919-1920 Ziem Pótnocno-Wschodnich opisanie, oprac. J. GierowskaKałłaur, Warszawa 2011.

Russakâ pečat'w Rige: iż istorii gazety Segodnâ 1930-h godov, oprac. J. Abyzov, L. Flejšman, B. Ravdin, kn. I, Stanford 1997.

Sočineniâ russkogo perioda, t. I, red. Ł. Flejšman, Moskva 2011.

Solski W., Moje wspomnienia, Warszawa 2008.

Stołypin A., Cesarstwo $i$ wygnanie, Warszawa 1998.

Struve P. V., Dnevnik Palitika (1925-1935), Moskva-Pariž 2004.

Vojcehovskij S., Epizody, London-Kanada 1978.

Wędziagolski K., Pamiętniki, Warszawa 2007.

Żongołłowicz B., Dzienniki 1930-1936, oprac. D. Zamojska, Warszawa 2004.

Opracowania

Chojnowski A., Koncepcje polityki narodowościowej rządów polskich w latach 1921-1939, Wrocław 1979.

Czarnecka R., Organizacja Oddziału II Sztabu Generalnego WP (Sztabu Gtównego) i jego ekspozytur terenowych $w$ latach 1918-1939, w: Wywiad i kontrwywiad wojskowy II RP, red. T. Dubicki, Łomianki 2010.

Gierowska-Kałłaur J., Straż Kresowa a Zarzad Cywilny Ziem Wschodnich. Współdziałanie czy rywalizacja?, Warszawa 1999.

Ismagulova T., Russkaâ emigraciâ v Polše (Vladimir Brand - poet i woin ,russkoj Waršavy”), w: Zarubežnaâ Rossiâ 1917-1939 gg. Sbornik stacej, red. V. J. Černâev, Sankt Peterburg 2010.

Juzwenko A., Polska a „biała” Rosja (od listopada 1918 do kwietnia 1920 r.), Wrocław 1973.

Kočik W., Razvedčiki i rezidenty GPU za predelami otčiznyj, Âuza 2004, s. 469, http://m.tululu. org/bread_55558_469.xhtml (dostęp: 2 I 2015).

Kovtun I., Gribkov I., Žukov D., Osobyj štab Rossiâ, Moskva 2011.

Mitzner P., Warszawski „Domek w Kołomnie”, Warszawa 2014.

Nowak A., Polska i trzy Rosje. Studium polityki wschodniej Józefa Pitsudskiego (do kwietnia 1920 roku), Kraków 2001.

Obłąkowska-Galanciak I., Gorzkie gody... Publicystyka i literacka działalność Dymitra Fiłosofowa na emigracji, Olsztyn 2001.

Pepłoński A., Wywiad polski na ZSRR 1921-1939, Warszawa 1996.

Pepłoński A., Wywiad w wojnie polsko-bolszewickiej1919-1920, Warszawa 1999.

Pipes R., Struve Liberal on the Right, 1905-1944, London 1980.

Stanisławski W., Myśl polityczna emigracji rosyjskiej w II Rzeczpospolitej: interpretacje przeszłości i koncepcje polityczne, mps. pracy doktorskiej w Bibliotece Instytutu Historycznego UW.

Suławka A. R., Idea wspótpracy polsko-rosyjskiej w myśli politycznej rosyjskiej emigracji w Polsce (lata 1918-1939), „Przegląd Filozoficzny” 2013, t. LXXXVII, z. 3, s. 221-238.

Zielińska N., Towarzystwo Straży Kresowej 1918-1927, Lublin 2006.

\section{Inspiration and Forms of the Cooperation of Polish State Institutions with the Publishers and Editorial Boards of Russian Periodicals in 1919-1935 - an Outline}

The inspiration and cooperation of Polish state institutions with the publishers and editorial boards of Russian periodicals from 1919 exerted a considerable impact on the functioning of the Russian émigrés and minority in Poland as well as the large number of Russian-speaking readers residing in the Eastern Borderlands.

This article is an outline of the activity conducted by the Society of the Eastern Borderland Guards, the Ministry of Internal Affairs, and the Second Department of the General Staff vis a vis the Russian press. The author discussed the reasons for the interest of the Polish authorities in the Russian press and attempted to assess the effects of this activity. Furthermore, by resorting to 
the Russian example he tried to present certain constant mechanisms of the undertakings of Polish institutions, which embarked upon similar initiatives also in relation to the press of other minority and émigré groups. Finally, the article distinguishes several types of inspiration of the Russian press.

The introduction offers a concise examination of the circumstances of the Russian influx in Poland after 1918, the number of the Russians, and their scattering across Polish territory.

The first part focuses on Polish-Russian contacts during the Polish-Bolshevik war, with the author discussing the structure of the Russian press in 1919-1920 and the first inspirationoriented operations. Upon the basis of the example of the Vladimir Horvitz-Samoylov case attention is drawn to the threat posed by cooperation with the Russians.

The second part of the text deals with the use made of wartime experiences for the development of the inspiration of Russian periodicals outside Poland.

The following fragment considers periodicals addressed chiefly to local readers and describes two divergent instances: „Novaya Rossiya” and „Volinskoe Slovo”.

The last part brings the reader closer to the activity of Dmitry Filosofov, one of the leaders of the Russian émigrés in Poland. The article places particular emphasis on plans of expanding Filosofov's press endeavours under Polish auspices so as to encompass important domestic and foreign periodicals that, associated with „Za Svobodu!”, could have resulted in a prominent press concern. This would have been an extremely essential achievement aimed at promoting the idea of a ,third Russia" in accordance with the conception launched by Filosofov and, at the same time, the notions propounded by the Polish state, which would have gained a powerful propaganda instrument both at home and abroad.

The article ends with a summary of the conclusions and an assessment of the policy carried out by the Polish state in 1919-1935. 